\title{
Effects of Polishing Techniques on the Staining of Two Nano-Tooth Coloured Materials
}

(Kesan Penggilapan ke atas Pewarnaan Dua Bahan Tampalan Berwarna Gigi Nano)

Kui Fei TEO, ZuRYATI AB-GHANI* \& ZAid HAMEed MoHAmmed Ali

\begin{abstract}
Surface polishing affect the staining of nano-tooth coloured materials. Here we studied the effect of tea and coffee staining on polished nano-composite resin and nano-ormocers. Eighty-four discs $(5 \times 2 \mathrm{~mm})$ of Filtek $Z 350$ and Ceram X were fabricated using acrylic molds and polished with either: (1) Sof-lex (2) Enhance/Pogo (3) control (no polishing-Mylar). After polishing, the tests materials were immersed in either tea or coffee ( $n=7)$, for 48,96 and $168 \mathrm{~h}$ at $37^{\circ} \mathrm{C}$. The colour difference ( $\triangle E$ ) values were assessed with a spectrophotometer (Cecil CE 2021 UV/VIS), the data were analysed using Kruskal-Wallis Test. The results showed that polishing significantly affected the $\Delta E$ values of both materials $(p<0.05)$. In all groups, Ceram X showed less staining than Filtek Z350. Both Filtek Z350 and Ceram X also reacted differently in coffee and tea. Significant $\triangle E$ values for Filtek Z350 obtained with different polishing techniques exposed to coffee in ascending order: Sof-lex $<$ Enhance/Pogo $<$ Mylar strip. For Ceram X, significant $\triangle E$ values obtained in exposure to tea in ascending order: Pogo < Mylar < Sof-lex. Mylar caused more staining in Filtek Z350 whilst Sof-Lex caused the least staining. However, in Ceram X, Enhance/Pogo caused the least staining. In conclusion, Ceram X is more colour stable than Filtek Z350. It may be suggested to always use the polishing system produced by the same company that produces the restorative material for better staining resistant.
\end{abstract}

Keywords: Nano-tooth coloured dental materials; polishing techniques; staining

\section{ABSTRAK}

Penggilap permukaan boleh mempengaruhi pewarnaan bahan tampalan berwarna gigi nano. Kajian ini dibuat untuk mengesan pewarnaan teh dan kopi pada resin nano komposit dan nano-ormocers yang digilap. Lapan puluh empat cakera bersaiz $5 \times 2 \mathrm{~mm}$, yang dibuat daripada Filtek Z350 dan Ceram X menggunakan acuan akrilik, digilap dengan: (1) Sof-lex (2) Enhance/Pogo (3) kawalan (tiada penggilap-Mylar). Selepas penggilapan, bahan-bahan ujian direndam ke dalam teh atau kopi $(n=7)$, selama 48, 96 dan 168 jam pada suhu $37^{\circ} \mathrm{C}$. Perbezaan warna ( $(\Delta E)$ dinilai menggunakan spektrofotometer (Cecil CE 2021 UV/VIS), data dianalisis menggunakan Kruskal-wallis Test. Keputusan analisis menunjukkan penggilapan mempengaruhi nilai pewarnaan kedua-dua bahan tampalan berwarna gigi nano $(p<0.05)$. Dalam semua kumpulan, Ceram X menunjukkan kesan perwarnaan yang lebih berbanding Filtek Z350. Filtek Z350 dan Ceram X juga bertindak balas secara berbeza dalam kopi dan teh. Perbezaan bacaan signifikan $\triangle E$ bagi Filtek Z350 di dalam kopi adalah seperti berikut: Sof-lex < Enhance/Pogo < Mylar strip manakala perbezaan bacaan signifikan $\triangle E$ di dalam teh untuk Ceram X adalah Pogo $<$ Mylar $<$ Sof-Lex. Penggunaan mylar strip sahaja ke atas Filtek Z350 menyebabkan lebih banyak pewarnaan, manakala Sof-Lex menyebabkan pewarnaan berkurangan. Penggunaan Enhance/Pogo ke atas Ceram X menyebabkan pewarnaan berkurangan. Kesimpulannya, Ceram Xadalah lebih stabil dalam kesan pewarnaan berbanding dengan Filtek Z350. Cadangan mungkin boleh dibuat untuk sentiasa menggunakan sistem penggilap yang dihasilkan oleh syarikat yang sama yang menghasilkan bahan tampalan bagi mengekalkan warna lebih lama.

Kata kunci: Bahan tampalan warna gigi nano; pewarnaan; teknik penggilapan

\section{INTRODUCTION}

Increasing demand in aesthetic dentistry is affecting the development of new tooth coloured restorative materials. Unaesthetic teeth due to hypoplasia, fluorosis, fractures, caries, shape or form irregularities can be treated with different approaches, including conservative, preventive and aesthetic techniques (Guler et al. 2009). Composite resins are now widely used as direct aesthetic restoration because of their excellent aesthetic properties. In 1998, a new type of resin composite was introduced to dentistry: The organically modified ceramic (ormocer) Multifunctional urethane and thioether methacrylate alkoxysilanes have been used as sol-gel precursors for synthesis of inorganic-organic copolymer composite 
materials for dental application. There has been a lot of improvement in the clinical performance of the tooth coloured dental materials along with the introduction of nanotechnology into dentistry.

However, discolouration of these materials may result in patient dissatisfaction and is a primary cause their replacement. The discolouration may be either intrinsic or extrinsic. The intrinsic factors involve the discolouration of the resin material itself whereas, extrinsic factors include staining by adsorption or absorption of colorants as a result of contamination from exogenous sources (Guler et al. 2009).

Finishing refers to the gross contouring of surfaces of the restorations to obtain the desired anatomy. Polishing refers to the lessening of roughness and scratches created by finishing instruments (Marigo et al. 2001). Finishing and polishing are significant procedures after placement of resin-based composite restorations. Enhancement of longevity and esthetics of the restoration can be obtained by proper finishing and polishing (Weitman \& Eames 1975).

Spectrophotometer has been used to measure colour change in dental materials. A spectrophotometer is a photometer devices for measuring light intensity as a function of the colour, or the wavelength of light. A spectrophotometer consists of two instruments, namely a spectrometer for producing light of any selected colour (wavelength), whereas photometer for measuring the intensity of light. Visible region 400-700 nm spectrophotometry is used extensively in calorimetry science.

Several studies have been conducted on the color stability of nanocomposite materials (Avsar et al. 2015; Reddy et al. 2013). However, the effect of different polishing methods on the color difference of nanocomposite material has not been completely clarified.

The purpose of this study was to investigate the effect of different polishing methods on the colour stability of the nano-ormocer (Ceram X) and nanocomposite (Filtek Z350) upon exposure to staining agents. Furthermore, this study was carried out to add values to the studies that have been conducted on colour stability of nanocomposite resin finished with various polishing systems. It may be hypothesized that the surface finishing and polishing treatments significantly affect the staining of nano-tooth coloured materials. Furthermore, different polishing systems may resist staining differently in nano-tooth coloured materials.

\section{MATERIALS AND METHODS}

Acrylic molds were used to prepare $84(5 \times 2 \mathrm{~mm})$ discs specimens, 42 discs were made of Filtek Z350 (3M ESPE, USA) and the other half were Ceram X (Dentsply, Germany), covered by mylar strip and pressed flat with a glass slide. Materials were manipulated and polymerized according to manufacturer's instructions for the various products. All discs were photopolymerized using conventional light- curing unit Eli par ${ }^{\mathrm{TM}}$ Free Light 2 LED, (3M ESPE, USM) with a light intensity of $1000 \mathrm{~mW} /$ $\mathrm{cm}^{2}$ with the light tip held approximately $1 \mathrm{~mm}$ away from the specimens, $20 \mathrm{~s}$ on each side. Following light curing, the specimens were placed in distilled water for $24 \mathrm{~h}$ to ensure complete polymerization (Zuryati et al. 2013). The details of the restorative materials used in this study are shown in Table 1. The tested materials were further divided into three groups of fourteen specimens according to the different surface polishing procedures, Group 1 polished with Sof-lex (3M ${ }^{\mathrm{TM}}$ ESPE, St. Paul, MN, USA) Group 2 polished with Enhance/Pogo (Dentsply/Caulk, Milford, DE, USA) and Group 3 specimens served as the control group with no polishing procedure applied. Table 2 shows the polishing system used in this study. In the Enhance/Pogo (Dentsply/Caulk, Milford, DE, USA) groups, the specimens were finished with Enhance disc followed by polishing with Pogo discs. In the Sof-lex ( $3 \mathrm{M}^{\mathrm{TM}}$ ESPE, St. Paul, MN, USA) group, the specimens were polished with a series of polishing discs for $10 \mathrm{~s}$ for each disc (coarse, medium, fine and superfine). The same slow speed handpiece was used for all systems. The polishing procedure used consisted of repetitive strokes for $40 \mathrm{~s}, 10 \mathrm{~s}$ per step of the system as to prevent heat build-up and grooves formation. A conscious effort was made to standardize the strokes, downward force and the number of strokes for each polishing procedure (Zuryati et al. 2013). After polishing, baseline colour of the

TABLE 1. Details of the restorative materials

\begin{tabular}{|c|c|c|}
\hline Materials & Composition & Manufacturer \\
\hline Filtek $\mathrm{Z} 350$ shade $\mathrm{A} 2$ & $\begin{array}{l}\text { Filler: } \\
\text { - aggregated zirconia/silica cluster filler } 0.6 \text { to } 1.4 \text { microns with primary particle } \\
\text { size of 5-20nm } \\
\text { Resin matrix: } \\
\text { - bis-GMA, UDMA,TEGMA and bis-EMA }\end{array}$ & 3M ESPE, USA \\
\hline Ceram X Shade A2 & $\begin{array}{l}\text { Filler: } \\
\text { - Barium- aluminium-borosilica glass } 1.1-1.5 \mu \mathrm{m} \text {, } \\
\text { - Methacrylate functionalized silicon dioxide nanofiller } \\
\text { Resin matrix: } \\
\text { - dimethacrylate resin, } \\
\text { - methacrylic modified polysiloxane }\end{array}$ & Dentsply, Germany \\
\hline
\end{tabular}

Bis-GMA, bisphenol-glycidyl methacrylate; BIS-EMA,ethoxylated bisphenol A glycol dimethacrylate; UDMA, urethane dimethacrylate; TEGDMA, triethylene glycol dimethacrylate 
TABLE 2. Polishing systems used

\begin{tabular}{lll}
\hline Polishing system & Polishing and finishing technique & Manufacturer \\
\hline Enhance Finisher & Polymerized Urethane Dimethacrylate Resin & Denstply/ Caulk, Milford, DE, USA \\
& Aluminium Oxide & \\
& Silicon Oxide & \\
& Plastic latch-type mandrel & \\
& Polymerized Urethane Dimethacrylate Resin & Denstply/ Caulk, Milford, DE, USA \\
Pogo Polisher & Fine Diamond Powder & \\
& Silicon Oxide & \\
& Plastic latch-type mandrel & 3M ESPE, St Paul, MN, USA \\
Sof-lex & Coarce aluminium oxide disc $(55 \mu \mathrm{m})$ & \\
& Medium aluminium oxide disc $(40 \mu \mathrm{m})$ & \\
& Fine aluminium oxide disc $(24 \mu \mathrm{m})$ & Mylar, Dupont,Wilmington,Del., USA \\
\hline
\end{tabular}

test materials was measured by taking diffuse reflectance absorbance readings with a spectrophotometer (Cecil CE 2021 UV/VIS Spectrophotometer) with $8 \mathrm{~mm}$ aperture diameter. A standardization of $600 \mathrm{~nm}$ wavelength (Taira \& Yamaki 1995), within the visible colour spectrum was set for all tested materials. The measurement was conducted by aligning the centre of $5 \mathrm{~mm}$ diameter specimen, directly over $8 \mathrm{~mm}$ diameter targeting aperture of the spectrophotometer. An average of three absorbance readings were taken for each specimen.

\section{Preparation of The Staining Solutions}

Coffee (Nescafe Classic; Nestlé Suisse SA, Vevey, Switzerland) (3.6 g, at $\mathrm{pH} 4.50$ ) was dissolved in 300 $\mathrm{mL}$ of boiling distilled water according to manufacturer's recommendation. After 10 min of stirring, the solution was filtered through a filter paper, following manufacturer's instruction. The tea (Yellow Label Tea; Lipton, Rize, Turkey) was prepared by immersing 2 prefabricated tea bags $(2 \times 2 \mathrm{~g}$ at $\mathrm{pH} 4.44)$ into $300 \mathrm{~mL}$ of boiling distilled water according to manufacturer's recommendation for $10 \mathrm{~min}$.

After that, the test materials were subdivided into 2 groups $(n=7)$. All specimens in each group were immersed into either coffee or tea for 48,96 and $168 \mathrm{~h}$ at $37^{\circ} \mathrm{C}$. Group A $(n=7)$ was immersed into $100 \mathrm{~mL}$ of coffee at $37^{\circ} \mathrm{C}$. Group B $(n=7)$ was immersed into $100 \mathrm{~mL}$ of tea at $37^{\circ} \mathrm{C}$. After $48 \mathrm{~h}$, the specimens were rinsed with distilled water for $5 \mathrm{~min}$ and blotted dry with tissue paper before colour measurement. In order to produce reproducible readings, the stained specimens were allowed to air-dry at room temperature for $30 \mathrm{~min}$ before measurements (Moore et al. 2008). After that, colour reading was made using the spectrophotometer in the manner described for baseline reading.

The colour differences $\Delta \mathrm{E}^{*}$ between 2 colour measurements was as follows:

$$
\Delta \mathrm{E}^{*}=\mathrm{E}_{2}(\mathrm{~A})-\mathrm{E}_{\text {Baseline reading }}(\mathrm{A})
$$

Thereafter, the specimens were placed back into the staining agent for another $48 \mathrm{~h}$ to record the exposure at
$96 \mathrm{~h}$. The specimens were washed and measured of the colour changes compared to baseline. Last measurement was done at $168 \mathrm{~h}$ ( 7 days) and the colour changes were compared to the baseline as well. SPSS version 17.0 (SPSS Inc. 2008) was used for data entry and statistical analysis. Means were analysed using Kruskal-wallis Test to evaluate the effect of polishing on colour changes after exposure to coffee or tea. The comparison between tea and coffee was evaluated using Mann-Whitney test, at significant level of $p<0.05$.

\section{RESULTS AND DISCUSSION}

Colour stability is an important consideration for aesthetic restoration. There have been a lot of studies being carried out in vitro for a variety of restorative materials with different polishing techniques (Guler et al. 2009, 2005; Miotti et al. 2016; Patel et al. 2004; Reis et al. 2003; Sarac et al. 2006). The present study measured the colour stability of nanocomposite resin and nano-ormocer using different polishing systems. Coffee and tea were used in this study as a colorant agent because of their frequent consumption in daily life.

Stober et al. (2001) reported that a period of $24 \mathrm{~h}$ of artificial treatment was too short to investigate discolouration of dental composites. According to Guler et al. (2009), the storage of $48 \mathrm{~h}$ was selected as the coffee manufacturer states that the average time for the consumption of one cup of a drink is $15 \mathrm{~min}$ and among coffee drinkers, the average consumption of coffee is 3.2 cups per day. Therefore, the $48 \mathrm{~h}$ storage time stimulated consumption of the drink over a two- month period.

In general, the pattern of the bar charts (Figures 1-6) show less colour changes in Ceram X compared to Filtek Z350 when the control group (Mylar) was exposed to either tea or coffee. The result of this study is in agreement with a study conducted by Nuaimi and Ragab (2014). Some studies reported that the composition of the resin materials influenced the colour change of a resin material (AbuBakr et al. 2000; Lee et al. 2005; Schulze et al. 2003). It was found that incorporation of greater amounts of TEGDMA resulted in an increase in water uptake in Bis-GMA based 
$\Delta \mathrm{E}^{*}$ of Filtek Z350 after 48, 96 and $168 \mathrm{~h}$

exposure in coffee and tea after using mylar

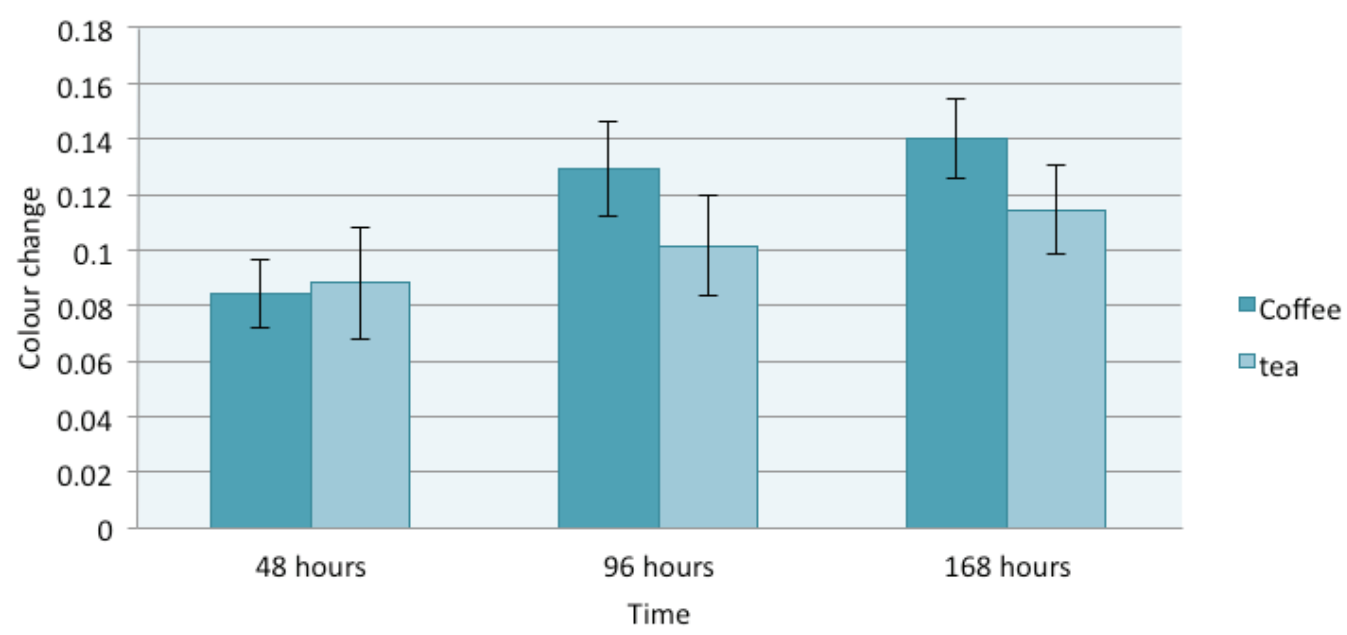

FIGURE 1. Mean colour change $\Delta \mathrm{E}^{*}$ in the control group (Mylar) of Filtek Z350 after being stained with coffee and tea

$\Delta \mathrm{E}^{*}$ of Ceram $\mathrm{X}$ after 48,96 and $168 \mathrm{~h}$ exposure in coffee and tea after using mylar

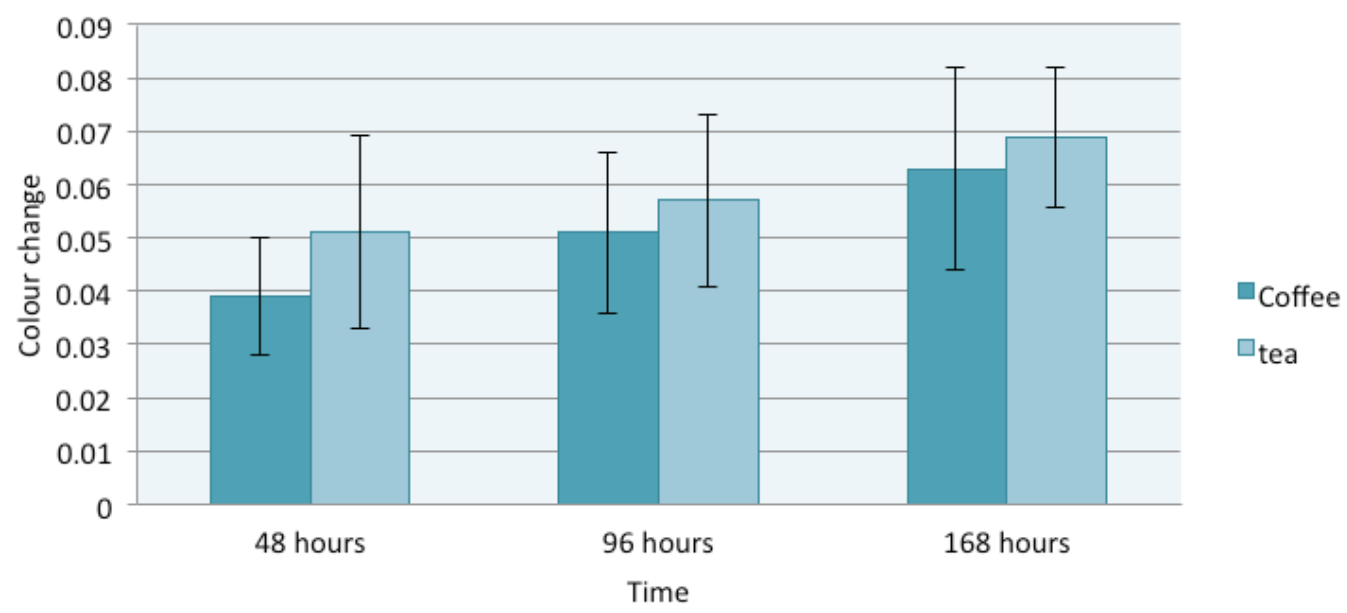

FIGURE 2. Mean colour change $\Delta \mathrm{E}^{*}$ in the control group (Mylar) of Ceram X after being stained with coffee and tea

$\Delta \mathrm{E}^{*}$ of Filtek Z350 after 48, 96 and $168 \mathrm{~h}$

exposure in coffee among polishing techniques

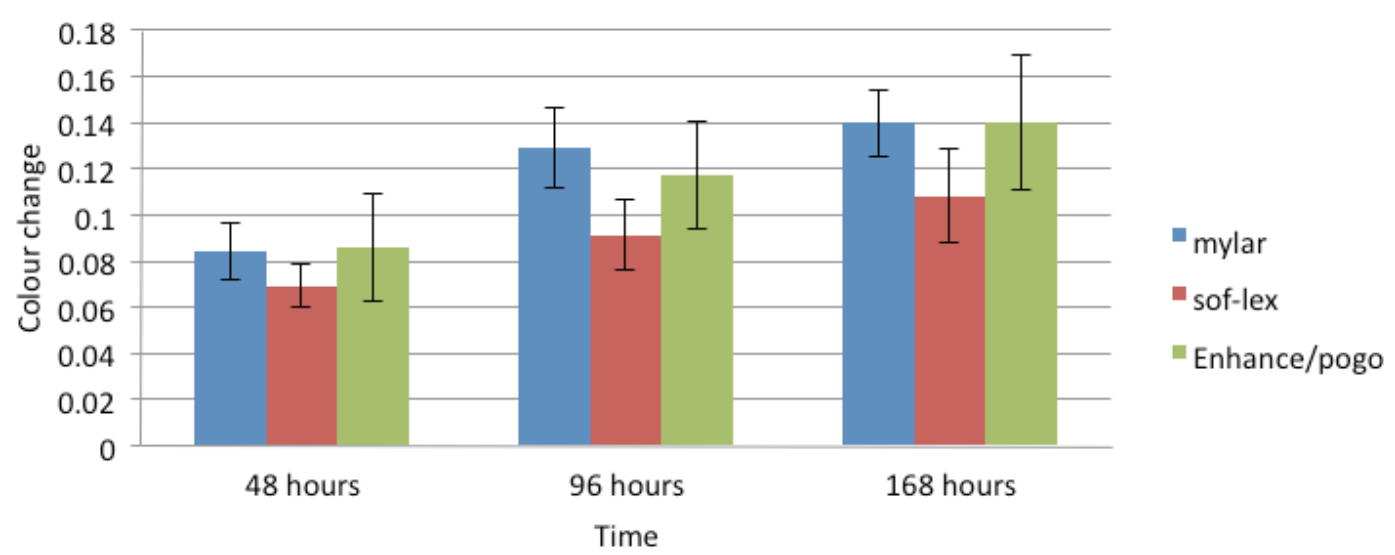

FIGURE 3. Comparison of colour changes $(\Delta \mathrm{E})$ of Filtek Z350 after 48, 96 and $168 \mathrm{~h}$ exposure to coffee after being polished with different polishing systems 
$\Delta \mathrm{E}^{*}$ of Filtek Z350 after 48, 96 and $168 \mathrm{~h}$ exposure in tea among polishing techniques

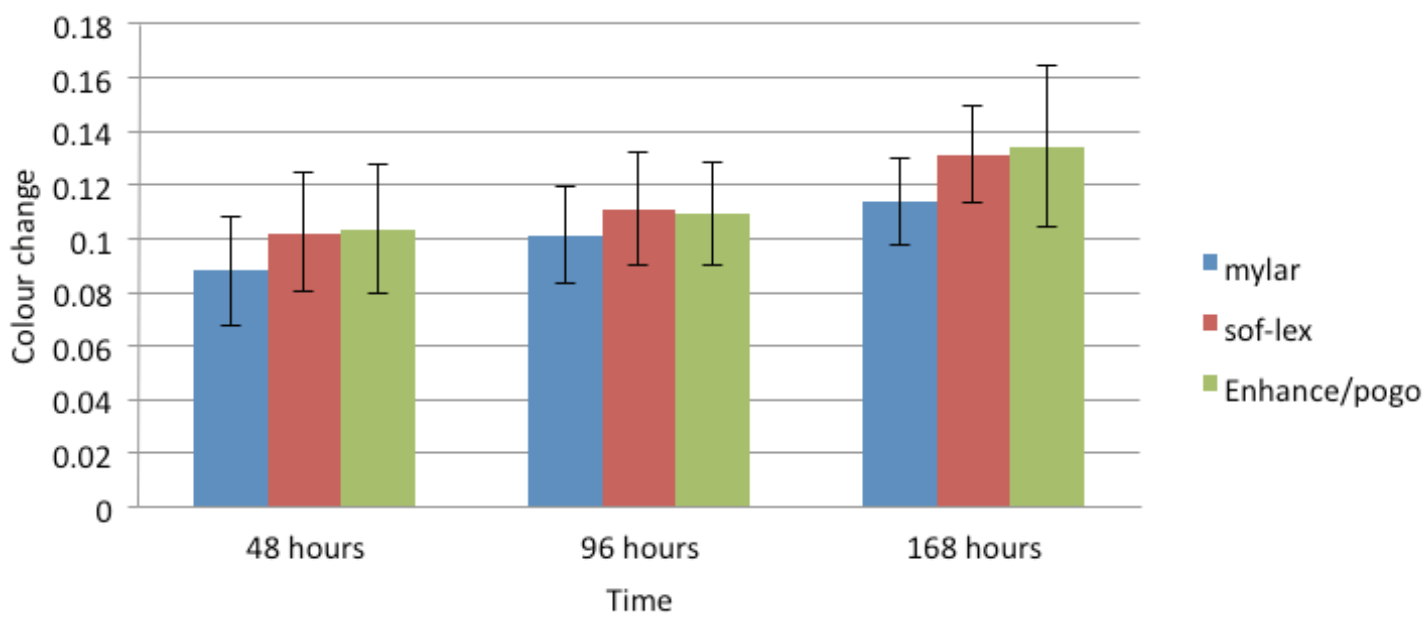

FIGURE 4. Comparison of colour changes $(\Delta \mathrm{E})$ of Filtek Z350 after 48, 96 and $168 \mathrm{~h}$ exposure to tea after being polished with different polishing systems

$\Delta \mathrm{E}^{*}$ of Ceram $\mathrm{X}$ after 48,96 and $168 \mathrm{~h}$

exposure to tea among polishing techniques

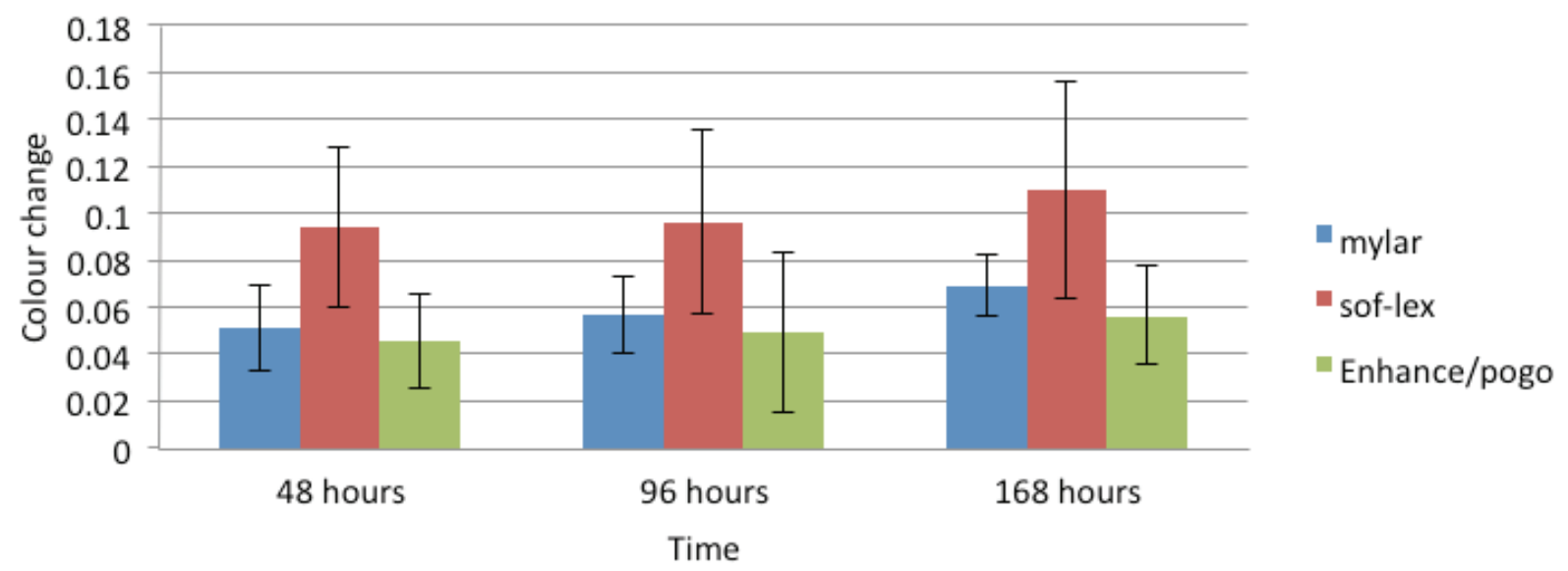

FIGURE 5. Comparison of colour changes $(\Delta \mathrm{E})$ of Ceram $\mathrm{X}$ after 48, 96 and $168 \mathrm{~h}$ exposure to tea after being polished with different polishing systems

$\Delta \mathrm{E}^{*}$ of Ceram $\mathrm{X}$ after 48,96 and $168 \mathrm{~h}$

exposure to coffee among polishing techniques

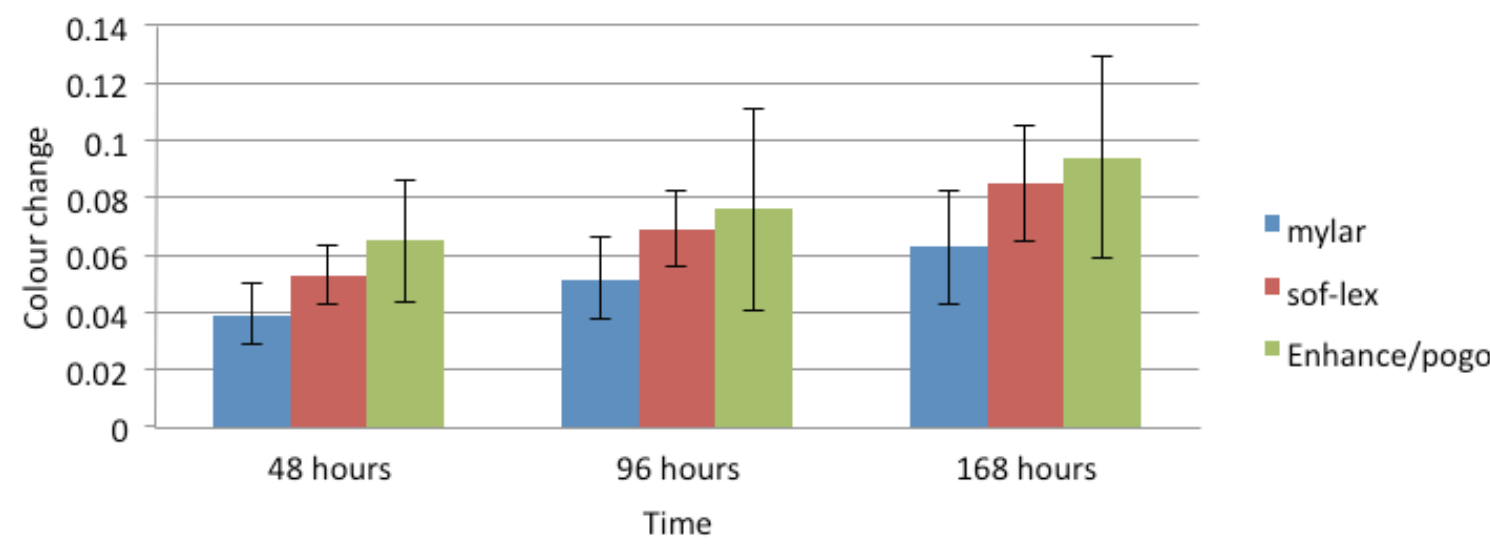

FIGURE 6. Comparison of colour changes $(\Delta \mathrm{E})$ of and Ceram $\mathrm{X}$ after 48,96 and $168 \mathrm{~h}$ exposure to coffee after being polished with different polishing systems 
resins. Kalachandra and Turner (1987) reported that this was due to increased surface hydrophilicity. Hydrophilic groups such as the ethoxy group in TEGDMA are thought to show affinity with water molecule by hydrogen bonding to oxygen (Imizato et al. 1999). Filtek Z350 contains Bis-GMA, bisphenol-glycidyl methacrylate; BIS-EMA, ethoxylated bisphenol A glycol dimethacrylate; UDMA, urethane dimethacrylate; TEGDMA, triethylene glycol dimethacrylate. Ceram $\mathrm{X}$ on the other hand is a nano ceramic composite containing dimethacrylate resin, methacrylic modified polysiloxane in its resin matrix. This would probably explain Ceram $\mathrm{X}$ being more colour stable than Filtek Z350.

It has been noted that a composite with large filler particles are more prone to water aging discoloration than a composite with small filler particles, which is in line with the hydrolytic degradation matrix filler interfaces (AbuBakr et al. 2000; Schulze et al. 2003). Thus, a composite with large filler particles has more colour permeability than a composite with small filler particles. Filtek Z350 has filler size of 5-20 nm compared to Ceram $\mathrm{X}$ which comprises organically modified ceramic nanoparticles 2-3 nm, nanofillers of $10 \mathrm{~nm}$ and combined with conventional glass fillers of $\sim 1 \mu \mathrm{m}$. This may also explain the colour stability of Ceram X compared to Filtek Z350. Ferracane et al. (1990) reported that resin based materials with lower filler contents have shown to have poor colour stability. Filtek Z350 has filler loading of $78.5 \%$ by weight or $58.5 \%$ by volume whereas Ceram $\mathrm{X}$ has filler content up to $77 \%$ by weight or up to $55 \%$ by volume. However, in this study, the small difference in the filler loading does not seem to affect the colour stability.

Figures 1 and 2 show the mean colour change $\Delta \mathrm{E}^{*}$ in the control group (Mylar) of Filtek Z350 and Ceram X, respectively, after being stained with coffee and tea. Both Filtek Z350 and Ceram X reacted differently in coffee and tea. Filtek Z350 adsorbed more coffee at 96 and 168 $\mathrm{h}(p=0.01)$ than tea, while Ceram $\mathrm{X}$ adsorbed more tea colourant compared to coffee. However, this was not statistically significant $(p>0.05)$. Previous findings (Um \& Ruyter 1991) showed that tea and coffee contain yellow colourants, which have different polarities. Higher polarity component, those in tea, are eluted first and lower polarity components, those in coffee are eluted later. Therefore, discolouration by tea was due to adsorption of polar colourants onto the surface of the materials. However, discolouration by coffee was due to both adsorption and absorption of colourants into the organic phase of the materials. Thus, tea staining in Ceram $\mathrm{X}$ was mainly on the surface whilst for Filtek Z350, the discolouration of coffee was more intrinsic.

Finishing and polishing are significant procedures after placement of resin-based composite restorations. Proper finishing and polishing have been related to less plaque retention and margin discolouration, thus, enhancing longevity and esthetics of the restoration (Weitman \& Eames 1975). The test groups in this study were polished with either Sof-lex disks or Enhance/pogo. The results of this study were in agreement with a study done by Barakah and Taher (2014). The surface finishing and polishing treatments significantly affected the staining of nano-tooth coloured materials and different polishing systems resisted staining differently in nano-tooth coloured materials.

Figures 3-6 show the comparison of colour changes $(\Delta \mathrm{E})$ of Filtek Z350 and Ceram X after 48, 96 and 168 $\mathrm{h}$ exposure to staining agents, after being polished with different polishing systems. Significant differences were found in $\Delta \mathrm{E}(p=0.01$ at $96 \mathrm{~h}$ and $p=0.02$ at $196 \mathrm{~h})$ with different polishing procedures when Filtek Z350 was exposed to coffee solution (Figure 3). Sof-lex produced the least colour change, followed by Enhance/pogo and Mylar strip (Sof-lex $<$ Enhance/Pogo $<$ Mylar Strip). This result is in agreement with Deljoo et al. (2016). However, there was no significant difference in colour change between the polishing techniques when Filtek Z350 were exposed to tea $(p>0.05)$, as shown in Figure 4. For Ceram $X$, there was a significant difference in colour change between the polishing techniques when the material was exposed to tea ( $p=0.00$ at $48 \mathrm{~h}, p=0.01$ at both $96 \mathrm{~h}$ and $168 \mathrm{~h}$ ). Enhance/ Pogo produced the least colour change, followed by Mylar strip and Sof-lex (Enhance/Pogo $<$ Mylar Strip $<$ Sof-lex) as shown in Figure 5. However, Ceram X showed no significant difference in colour changes between polishing techniques when the material was exposed to coffee solution $(p>0.05)$ and shown in Figures 6.

Coffee may stain by adsorption and by absorption of its colorants into the organic phase of resin composites (Van Groeningen et al. 1986). This absorption and penetration of colourant into organic phase were probably due to the compatibility of the polymer phase with yellow colourants of the coffee (Um \& Ruyter 1991). According to Koh et al. (2008), an ideal polishing system must have abrasive particles which are harder than the filler materials, therefore, allowing reduction of both the resin matrix and filler particles of the composites during polishing. If the abrasive particles were softer than the fillers, then only the resin matrix would be removed and filler particles would be protruding from the surface. The hardness of aluminium oxide is significantly higher than that of silicon oxide and generally, higher than most filler materials used in composite resin formulation (Reis et al. 2002). This statement supported this study results for Filtek Z350 (3M ESPE, USA), polished with Sof-lex (3M ESPE, USA), which only has aluminium oxide.

Ceram X polished with Enhance/Pogo which composed of aluminium oxide, silicon oxide and fine diamond powder may be harder than Ceram X, thus produced the least staining.

This is an in vitro study which has several limitations. The specimen surfaces were flat, whereas, clinically, restoration will have an irregular shape with convex and concave surfaces. Furthermore, the application of surface finishing procedures tested in this study may be difficult to perform clinically. The solution used in this study does not consider all substances to which materials may be exposed. The specimens were not stored in a humid environment. Other factors that could influence the degree of total colour 
change include thermal cycling, ageing or abrasion. These should be considered for future study.

\section{CONCLUSION}

Ceram $\mathrm{X}$ is more colour stable than Filtek Z350 when the materials are exposed to tea and coffee solutions. In Filtek Z350 (3M ESPE, USA), polishing it with Sof-lex (3M ESPE, USA) caused the least staining whilst in Ceram X (Dentsply, Germany), Enhance/Pogo (Dentsply, Germany) caused the least staining. Therefore, it may be suggested to always use the polishing system produced by the same company that produces the restorative material for better stain resistance.

\section{REFERENCES}

AbuBakr, N., Han, L., Okamoto, A. \& Iwaku, M. 2000. Color stability of compomer after immersion in various media. Journal of Esthetic and Dentistry 12: 258263.

Avsar, A., Yuzbasioglu, E. \& Sarac, D. 2015. The effect of finishing and polishing techniques on the surface roughness and the color of nanocomposite resin restorative materials. Advances in Clinical and Experimental Medicine 24(5): 881-890.

Barakah, H.M. \& Taher, N.M. 2014. Effect of polishing systems on stain susceptibility and surface roughness of nanocomposite resin material. The Journal of Prosthetic Dentistry 112(3): 625-631.

Deljoo, Z., Sadeghi, M., Azar, M.R. \& Bagheri, R. 2016. The effect of different polishing methods and storage media on discoloration of resin composites. Journal of Dental Biomaterials 3(2): 226-232.

Ferracane, J.L., Berge, H.X. \& Condon, J.R. 1998. In vitro aging of dental composites in water - effect of degree of conversion, filler volume, and filler/matrix coupling. Journal of Biomedical Materials Research 42: 465472.

Guler, A.U., Kurt, S. \& Kulunk, T. 2005. Effect of various finishing procedures on the staining of provisional restorative materials. The Journal of Prosthetic Dentistry 93(5): 453-458.

Guler, A.U., Guler, E., Yusel, A.C. \& Ertas, E. 2009. Effects of polishing procedures on color stability of composite resins. Journal of Applied Oral Science 17: 108-112.

Imazato, S., Tarumi, H., Kato, S. \& Ebisu, S. 1999. Water sorption and colour stability of composites containing the antibacterial monomer MDPB. Journal of Dentistry 27: 279-283.

Koh, R., Neiva, G., Dennison, J. \& Yaman, P. 2008. Finishing systems on the final surface roughness of composites. The Journal of Contemporary Practice 9: 138-145.

Kalachandra, S. \& Turner, D.T. 1987. Water sorption of polymethacrylate networks: Bis-GMA/TEGDMA copolymers. Journal of Biomedical Materials Research 21: 329-338.

Lee, Y.K., Lu, H. \& Powers, J.M. 2005. Effect of surface sealant and staining on the fluorescence of resin composites. The Journal of Prosthetic Dentistry 93: 260266.

Marigo, L., Rizzi, M., La Torre, G. \& Rumi, G. 2001. 3-D surface profile analysis: Different finishing methods for resin composites. Operative Dentistry 26: 562-568.

Miotti, L.L., Nicoloso, G.F., Durand, L.B., Susin, A.H. \& Rocha, R.O. 2016. Color stability of a resin composite: Effect of the immersion method and surface treatments. Indian Journal of Dental Research 27(2): 195-199.
Nuaimi, H.O. \& Ragab, H.M. 2014. Effect of aggressive beverage on the color stability of different nano-hybrid resin based composite. European Journal of General Dentistry 3(3): 190-193.

Patel, S.B., Gordan, V.V., Barrett, A.A. \& Shen, C. 2004. The effect of surface finishing and storage solutions on the color stability of resin-based composites. The Journal of the American Dental Association 135: 587-594.

Reddy, P.S., Tejaswi, K.L., Shetty, S., Annapoorna, B.M., Pujari, S.C. \& Thippeswamy, H.M. 2013. Effects of commonly consumed beverages on surface roughness and color stability of the nano, microhybrid and hybrid composite resins: An in vitro study. The Journal of Contemporary Dental Practice 14(4): 718-723.

Reis, A.F., Giannini, M., Lovadino, J.R. \& Ambrosano, G.M. 2003. Effects of various finishing systems on the surface roughness and staining susceptibility of packable composite resins. Dental Materials 19: 12-18.

Reis, A.F., Giannini, M., Lovadino, J.R. \& Dos Santos Dias, C.T. 2002. The effect of six polishing systems on the surface roughness of two packable resin-based composites. American Journal of Dentistry 15: 193-197.

Sarac, D., Sarac, Y.S., Kulunk, S., Ural, C. \& Kulunk, T. 2006. The effect of polishing techniques on the surface roughness and color change of composite resins. The Journal of Prosthetic Dentistry 96: 33-40.

Stober, T., Gilde, H. \& Lenz, P. 2001. Color stability of highly filled composite resin materials for facings. Dental Materials 17: 87-94.

Schulze, K.A., Marshall, S.J., Gansky, S.A. \& Marshall, G.W. 2003. Color stability and hardness in dental composites after accelerated aging. Dental Materials 19: 612619.

Taira, M. \& Yamaki, M. 1995. Studies on optical properties of a visible-light-cured dental composite resin by diffuse reflectance measurements. Journal of Materials Science Letters 14: 198-200.

Um, C.M. \& Ruyter, I.E. 1991. Staining of resin-based veneering materials with coffee and tea. Quintessence International 22(5): 377-386.

Van Groeningen, G., Jongebloed, W. \& Arends, J. 1986. Composite degradation in vivo. Dental Materials 2: 225-227.

Weitman, R.T. \& Eames, W.B. 1975. Plaque accumulation on composite surfaces after various finishing procedures. Oral Health 65: 29-33.

Zuryati, A.G., Qian, O.Q. \& Dasmawati, M. 2013. Effects of home bleaching on surface hardness and surface roughness of an experimental nanocomposite. Journal of Conservative Dentistry 16(4): 356-361.

Kui Fei Teo

Pusat Pakar Pergigian Seremban

Pejabat Kesihatan Pergigian Daerah Seremban

Jln Za'aba, 70100 Seremban, Negeri Sembilan Malaysia

Zuryati Ab-Ghani* \& Zaid Hameed Mohammed Ali

School of Dental Sciences, Health Campus

Universiti Sains Malaysia

16150 Kubang Kerian, Kelantan Darul Naim

Malaysia

*Corresponding author; email: zuryati@usm.my

Received: 11 May 2017

Accepted: 16 November 2017 
